\title{
PRODUCT PLACEMENT EFFECTS ON INTERNATIONAL SALES OF CLIENTS IN EXPORTED TURKISH SOAP OPERAS
}

\author{
BEHIYE BEĞENDIK ${ }^{5}$
}

\section{ABSTRACT}

Turkish soap operas have scored great success both in the home country and also in Middle East and Balkan countries recently. In Turkey producers and marketers discovered the power of soap operas. Thus as a promotional mix element product placement is widespreadly used in Turkish soap operas. On the other hand Turkish soap operas are broadcasted in more than 100 countries. Consequently the product placed in exported soap opera is seen by audience in foreign countries. This paper investigates the effect of product placement in Turkish soap operas to the sponsor firms' (clients') international sales. In other words it is questioned if Turkish placed products' international sales rise after soap operas' internationalization.

Qualitative research is done on 3 jewellery firms placing their products on soap operas. Study results finds out firstly the general product placement effects to the clients. This study also discover that the firms having a distribution channel in foreign countries evaluate the results after product placement differently from the firms that don't have distribution channel in foreign countries. Thus, this paper finds out the importance of distribution channel for international sales after product placement. Consequently distribution channel possession in foreign countries has been evaluated as a property of firm affecting product placement results especially the internatonal sales.

Keywords: Coding, product placement, qualitative analysis, soap opera internationalization Jel Classification: M16, M31, M37

\footnotetext{
${ }^{5}$ Dr. Öğr. Üyesi, Beykoz University, Civil Aviation Scool, Aviation Management, behiyebegendik@beykoz.edu.tr
} 


\section{IHRAÇ EDILEN TÜRK DIZILERINDE ÜRÜN YERLEŞTIREN IŞLETMELERIN ULUSLARARASI SATIŞLARINA ÜRÜN YERLEŞTIRMENIN ETKISi}

\section{ÖZET}

Türk dizileri yurt içinde ve özellikle Orta Doğu ve Balkanlar'da büyük başarı elde etmiştir. Türkiye'de yapımcılar ve pazarlamacılar dizilerin gücünü keşfetmişlerdir. Bu nedenle tutundurma karması elemanı olarak ürün yerleştirme Türk dizilerinde yaygın olarak kullanılmaktadır. Diğer yandan, Türk dizileri 100'den fazla ülkede yayınlanmaktadır. Dolayısıyla, ihraç edilen dizilere yerleştirilen ürünler yabancı ülkelerdeki izleyiciler tarafından da görülmektedir.

Bu makale, Türk dizilerinde ürün yerleştirmenin ürün yerleştiren sponsor işletmelerin uluslararası satışlarına etkisini incelemektedir. Bir başka ifade ile Türk dizilerinin uluslararasılaşmasından sonra dizilere yerleştirilen ürünlerin uluslararası satışlarının durumu araştırılmıştır.

Türk dizilerine ürün yerleştiren 3 kuyumcu işletme üzerinde kalitatif araştırma yapılmışır. Araştırma sonuçları ilk olarak ürün yerleştirmenin müşterilere genel etkilerini ortaya çıkarmıştır. Bununla birlikte çalışmada, yabancı ülkelerde dağıtım kanalı olan işletmelerin ürün yerleştirme sonuçlarını yabancı ülkelerde dağıtım kanalı olmayan işletmelerden farklı değerlendirdiği bulunmuştur. Bu nedenle, bu makalede ürün yerleştirme sonrasında uluslararası satışlar için dağıtım kanalının önemine dikkat çekilmektedir. Dolayısıyla, yabancı ülkelerde dağııım kanalına sahip olmak ürün yerleştirme sonuçlarına özellikle de uluslararası satışlara etki eden bir işletme özelliği olarak değerlendirilmektedir.

Anahtar Kelimeler: Kalitatif araştırma, kodlama, ürün yerleştirme, Türk dizilerinin uluslararasılaşması

Jel Sınıflaması: M16, M31, M37

\section{INTRODUCTION}

Increasing control of consumers on media use made it difficult to reach consumers and attract their attention on the massage content (Aydın and Orta, 2005: 8). Especially the digital programming offered audiences to watch the programmes whenever they want and also to skip advertisements without watching (Sapmaz and Tolon, 2014: 17). Thus, to reach and increase the advertisement efficiency, firms begin to shift different promotion mix elements other than traditional tools. Among the other promotion mix elements product placement attain importance as increasing attention by famous film artists, more persistent messages compared with traditional advertisement messages, having cost efficiency and percieved as less commercial by consumers (Argan, Nurtanıs Velioglu and Tokay Argan, 2007: 159). 
Although product placement in Turkey is in the golden age stage by the rise of soap operas recently, its roots of world implementation stands to novels two centuries ago (Lehu and Bressoud, 2008: 1083). The articles specified the earliest product placement example as Unilever's deliberate insertion of Sunlight Soap into several early Lumière films of the late 1890s (Gregorio and Sung, 2010: 83; Newell, et. al., 2006: 575; Reijsmerdal, et. al., 2010: 279). In the 1930s there were some activities that can be now gathered under the name of product placement. There were also other examples from mid-1940s based on the beginning in motion pictures (Newell, et al., 2006: 576). However after the Reese's Pieces candy placed in the film E.T. and sales increased by $65 \%$ in three months, this remarkable success formed growing interest for product placement in both marketing practitioners and academicians (Gupta and Lord, 1998: 48). After E.T.'s amazing stream a trend of scholarly research appeared for investigating the subjects about consumers (Gregorio and Sung, 2010: 83) in the early 1990s.

The previous studies focused on consumer side on the product placement context. d'Astous and Séguin examined (1999) consumer reactions to different types of product placement strategy in the context of television sponsorship using an experimental methodology. According to results, they offer firms to invest quiz/variety shows instead of mini-series/dramas to get higher visibility and to improve their corporate image (d'Astous and N. Séguin, 1999: 907).

Gregorio and Sung (2010) adopt the consumer socialization framework to examine placementrelated attitudes and behaviors among 3,340 adults, criticising the previous studies assessing on only students and small samples. Results show differences in both attitudes and behaviors across a range of demographic characteristics, including income, gender, and ethnicity.

Jin and Villegas (2007: 244-255) explored the role of prior brand evaluation and the placement of the product in humorous movies on the consumer judgment stage, investigating their effects on consumer response. The findings of the study indicate that the placement of product in humorous movie scenes result in positive emotional responses from consumers.

Gould, Gupta and Krauter (2000: 41-58) investigated consumer attitudes towards product placements, applying a survey on Austrian, French and American comsumers. The results point out that country, product and individual differences and their interactive effects have an impact on the acceptability of product placements and on potential purchase behavior.

Waldt, Toit and Redelinghuys (2007: 19) aimed to determine; if product placements in films increase realism of the film and respondents' recognition of brand name products placed in a film. A questionnaire on 220 undergraduate respondents resulted as product placements in films do have an effect on the realism of the film. Secondly, branded products placed in films are thought to inject a sense of realism into the film. The main findings and conclusions of this research confirm that the prominence of a product placement in a film affects the consumers' ability to recognise the placed product. 
Reijmersdal, Smit, Neijens (2010) also examined the brand placement effects on consumer behaviour. Moreover, they also investigated the effects of brand placement context factors on brand responses. Contrary to the prior researches the respondents watched television shows in their own homes instead of in a laboratory setting. The survey resulted as genre, programme attitude and the programme's informational value had positive effects on brand placement reactions.

The articles summarized till this point are the articles focused around the subjects related with consumers. Nearly all of the articles on the fact of consumer subjects researched product placement from movies. However, product placement is implemented not only in movies but also in television programmes and soap operas. In the literature minority of studies are about soap operas. Pervan and Martin treated the product placement in soap operas aiming to provide an initial exploratory examination into the types of products as well as the context and emotional outcomes of product consumption imagery in soap operas televised in US and New Zeland (Pervan and Martin, 2002: 102). When compared two countries about types of products and emotional outcomes, differences were observed.

Another paper on soap operas is Russell and Stern's (2006a) paper examining the influence of product placements in television serial comedies on consumer attitudes toward the products. While the research is focused on sitcoms, a specific type of soap operas, findings support the predictions that consumers align their attitudes toward products with the characters' attitudes to products and that this process is driven by the consumers' attachment to the characters (Russell and Stern, 2006a: 7).

Pastina (2001: 547-557) clarifying that product placements has been part of Brazilian television commercial strategy since the late 1960s, surveyed the role of gender, geographic location, and cultural capital in viewers' interpretations of textual insertions in rural areas.

Again Russell and Stern (2006b) organized a session composed of these three papers above, analyzing soap operas from Brazil, New Zealand, and the United States to examine the effect on consumers of consumption imagery and cultural reality depicted in.

Babacan, Akcali and Baytekin (2012: 1319-1331) aimed to present in examples from Turkish soap operas how product placement is used in accordance with different classification of product placement strategies.

Actually, the fact of product placement has been already both in literature and in practice in Turkish broadcasting. However the incredible rise of soap operas in Turkish TV channel drew marketers attention to product placement choice more consistent than before. In other words, the similtaneous rise of product placement and Turkish soap operas have developed opportunity for firms to promote their products. On the other hand, the success of Turkish soap operas in 
the home country has been noticed by the media managers in foreign countries with common culture. After first experimental exports of soap operas, Turkish soap operas got a snowball effect across the Middle East countries, Balkans, East Europe, North Africa, South America and Turkic Republics. It is stated that Turkish soap operas are watched in 142 countries with 400 million audiences reaching 350 million dolar export revenue (http://www.hurriyet.com.tr./turkdizileri-2-numara-40417302, 4 April, 2017).

These figures indicate that Turkish soap operas have bacome international hereafter. It also means that any product placed in Turkish soap opera will be promoted in international arena if the soap opera is exported. Thus, this paper aims to find out the effects of product placement in Turkish soap operas to international sales of the clients'. This subject, looking from the clients' window, will be new for the literature, as all the previous investigations are interested in the consumer side. Nonetheless, assessing product placement's results in international marketing arena will be new for literature, too.

In the first part of the paper, the product placement will be explained.

\section{a. Product Placement}

There are several explanations for product placement. Balasubramanian's (1994) explained product placement as 'a paid product message aimed at influencing movie (or television) audiences via the planned and unobtrusive entry of a branded product into a movie (or television program)' (Gupta and Lord, 1998: 47).

Russell and Belch (2005: 274) defined Brand placement as 'the purposeful incorporation of brands into editorial content'. Russell and Belch's definition differenciate from Balasubramanian's definition as not limiting the product placement implementation to only movies and television programs. Russell and Belch widens the baundiries to radio shows, songs and music videos, video games, plays, and even novels. Moreover, another difference is the fact that product placement is a paid activity or not. While Balasubramanian notes as a paid product message, Russell identifies that not all placements are paid.

Lehu and Bressoud clarified product placement as placing a product consists of putting a product and/or a brand into a movie scene where it can be seen and/or its name heard. The placement can either be paid for by the advertiser or be part of a barter deal concerning products and/or services such as logistics facilities (Lehu and Bressoud, 1990: 1084). In their definition Lehu and Bressoud enlarge the unpaid sitiuations of product placement activity as clearing that instead of payment different deals can be made between the production company and its clients like barters or logistic facilities. 


\section{The structure of product placement industry}

While product placement interest of both marketers and film producers grew tremendously, the atmosphere of industry has become to change. Priorly, there was a directly relationship between marketers and film producers in accordance with the mutual interests. Until the 1990s, product placement was implemented rather haphazardly and decisions had been based simply on institution (Karrh, et. al., 2003: 138). Growing sector and increasing revenues formed agents to manage this relationships. These agents lend movie makers free truckloads of merchandise and then charge manufacturers a fee for placing their merchandise in the film (Synder, 1992: 303). However when Coca-Cola purchased Colombia pictures, in all movies of Colombia pictures the use of Coca-Colas rivals were forbidden. Coca-Cola's intervention showed that studios could eliminate the middleman and instead deal directly with the manufacturers (Synder, 1992: 304). On the other hand, there is presently much more cordinated environment composed of two primary groups of professionals-placement agents and programme producers. Agents function as middlemen between marketers and producers, typically working on a retainer basis. The big film producers follow product placement activities not only from their own departments but also from placement agents as well (Karrh, et al., 2003: 75). Figure 1 depicts the various participants in the product placement industry. In this industry the marketers of the products are clients for film producers. Thus, marketers are named under the headline of clients.

Figure 1: Structure of Product Placement Industry

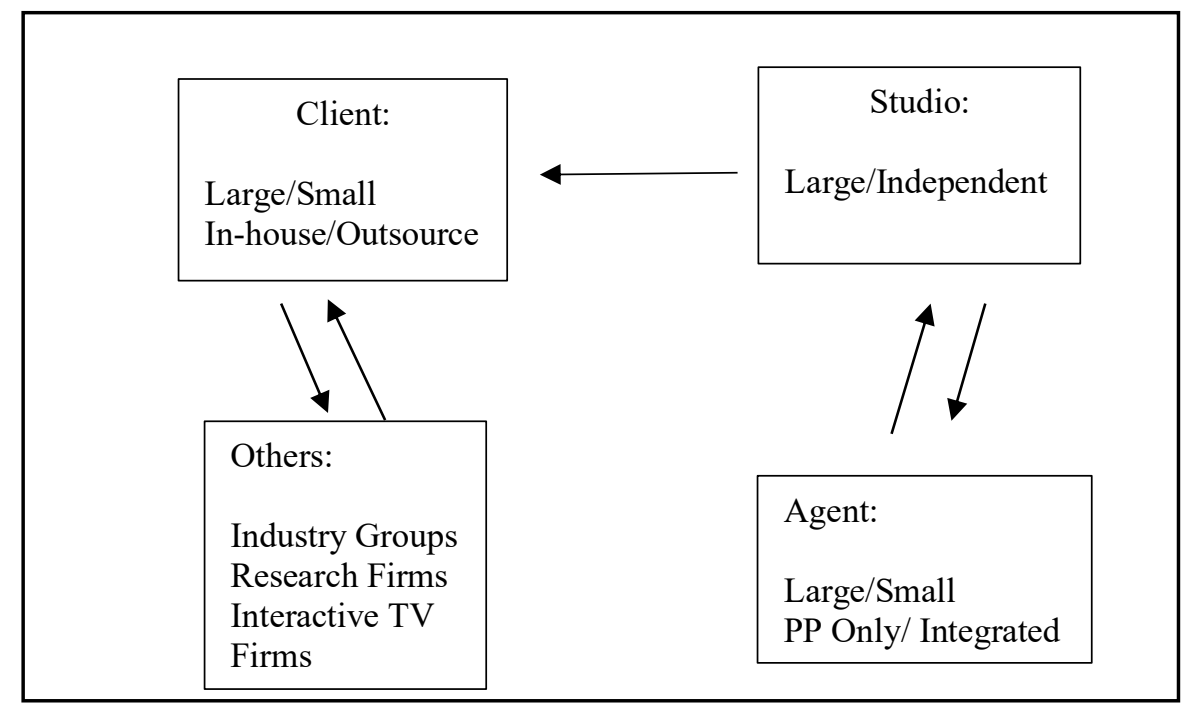

Source: Russell C. A. \& Belch M., (2005). A managerial investigation into the product placement industry, Journal of Advertising Research, · February 


\section{b. Purpose of the Research}

After the product placement in Turkish TV channels is allowed in March 2011, the obstacles for clients are swept to place products. In the first 6 months after the new regulation, product placement is implemented 1349 times (Kale, 2014: 47). Clients prefer this choice in soap operas as it can avoid zapping as being integrated in scenes. On the other hand product placement is percieved as non commercial by audiences when compared to advertisements. Thus it can be seen more than one product placement in nearly all Turkish soap operas. Also Turkish soap operas give invisible advantage to clients as being exported to more than 100 countries. International expansion of Turkish soap operas opens a new door for clients as being promoted in internationally. Thus, this paper investigates the relationship of clients' international sales and product placement in Turkish soap operas. It is also aimed to contribute the literature for leading the producers and the clients with the results.

\section{c. Research Model and Scope}

The mechanism of this research is set up on the basis of the previous and related literature discussed above. The research purpose is intended to investigate the acquisitions of the clients' while placed product is seen by consumers in foreign countries. In other words, it is aimed to learn if there is any contribution to clients' international sales by product placement in exported Turkish soap operas. Neverthemore if there is contribution for clients' international sales, it is searched how product placement affects this process. On the other hand, it is also searched if there are another effects to international sales concerned with the client independently of the product placement. Clearly, the research mechanism is described in Figure 2.

Figure 2. Model of Product Placement Effects to International Sales

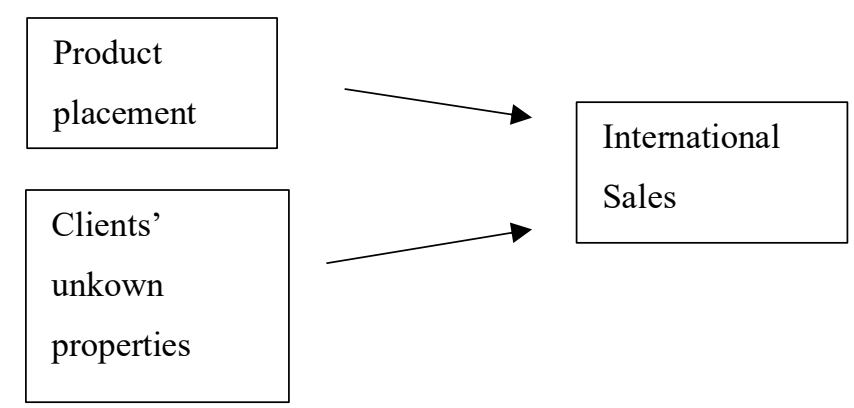

In the scope of study, the firms that placed their products in Turkish soap operas are reached. There are 3 firms in the research universe. They all accept to make face to face interview. The sample quantity is appropriate according to the 3-12 range in Yin and Eisenhardt' study. 


\section{d. Research method}

Qualitative research methods are applied, to develop a deep insight about the posture and events that represent research problem, to solve the problem and to ensure understanding the research problem better. Qualitative research methods are case studies, experiments, analysis of archives. In this article multiple case study approach is used, following Yin.

In case study, data can be gathered from different sources like: documentation, archives, interview, direct observation, and participant observation. This investigation is actualized by face to face interview.

Before evaluating the data gathered, it is required to register the data, to classify and to edit (Mayring, 2000: 72). Face to face interview is done with 3 firms that placed their product into Turkish soap operas. The interviews ranged in time from 40 to 60 minutes. The interviews were recorded and then transcription step was done. The research was supported by secondary data, by gathering information from sources like financial data, firms' presentation, product definitions, web sites, and news from media. By the help of secondary data, the construct validaty of the study was increased.

The most difficult part of qualitative research is data analysis. Every research carries different properties and same analysis methods cannot be used (Yıldırım and Simsek, 1999: 156). Thus, coding, one of the analysis of qualitative research, is preferred in this study. The purpose of coding is, finding the matter lying under the complexity and untidiness of data and conceptualizing it (Bas and Akturan, 2008: 73)

Coding is the vital point of qualitative research (Babbie, 2004: 376). Coding is composed of three stages. These stages are listed as below:

Open Coding: In open coding, data is separated in different pieces, investigated closely, compared for the purposes of similarities and differences. Thus, big data groups are shortened and obtained navigable pieces (Corbin and Strauss, 1998: 121).

Axial Coding: The key words with same and similar meanings are grouped and data is shortened (Corbin and Strauss, 1998: 142).

Selective Coding: It is the process of developing and refining the theory. In developing theory, categories are organized arround the central explanatory concept (Corbin and Strauss, 1998: 161).

Analyzing data by coding is done with codebooks. Codebooks are lists that codes are organized simply. In codebooks; questions, answers, the selected part of the answer, and the codes take place. 
During finding codes, techniques like repetitions and linguistic connectors are used (Bernard and Ryan: 2010). Nonetheless, descriptive analysis is used to help coding. Descriptive analysis is summarizing and interpreting data according to the determined themes (Yıldırım and Simsek, 2008: 224). In the study, to reflect the participants' opinions, direct citations take place frequently.

At last in data analysis taxonomy is used. Taxonomy is the model that a group of concepts are related with eachother (Bernard and Ryan, 2010: 139). Taxonomy has a view like hierarchical tree diagram (Denzin and Lincoln, 2000: 772).

\section{e. Reports of research findings}

It is more proper to start data analysis with evaluating the profiles of interviewed firms. All of the firms are in the jewellery industry. The first firm implemented product placement first in 2005 with The Bitter Life and Falling Leaves. Second firm implemented firm's first product placement in 2006 in the soap opera called 1001 Nights. The third firm didn't want to give information about the soap opera names and product placement dates.

In the interview form, there are questions on the general information about the product placement in Turkish soap operas and also the effects of product placement on international sales of the firms. Neverthemore it is also asked if there is another property of the firm that affects the international sales of the firm. Each answer is read for several times. By the techniques of repetitions and linguistic connectors, codes are found for again each answer. After open coding is ended for all answers, codes are listed. Codes that have same or near meaning, are incorporated into a common code that summarize them. Thus, number of codes are shortened by this way. And this operation is called as axial coding. At the end all the codes are read again. And the codes that are related about our subject are chosen.

\section{f. Results}

This research question is composed from our previous research which is not published yet. According to previous research soap opera exporters explained that the products placed on exported Turkish soap operas are so popular in foreign countries. Soap opera exporters added that foreign audiences even call soap opera producers to reach the products. Thus, depending on these explanations, it is questioned if Turkish placed products' international sales rise after soap operas' internationalization.

According to interview questions, firstly it is aimed to learn about general product placement effects to the clients. And it is also aimed to find out company's properties that affect product placement period. Below these effects are listed in Figure 3.

All of the respondents agree that product placement has a positive effect. Nonetheless their opinions diversificate in subtitles. 
Figure 3. Product Placement Effects

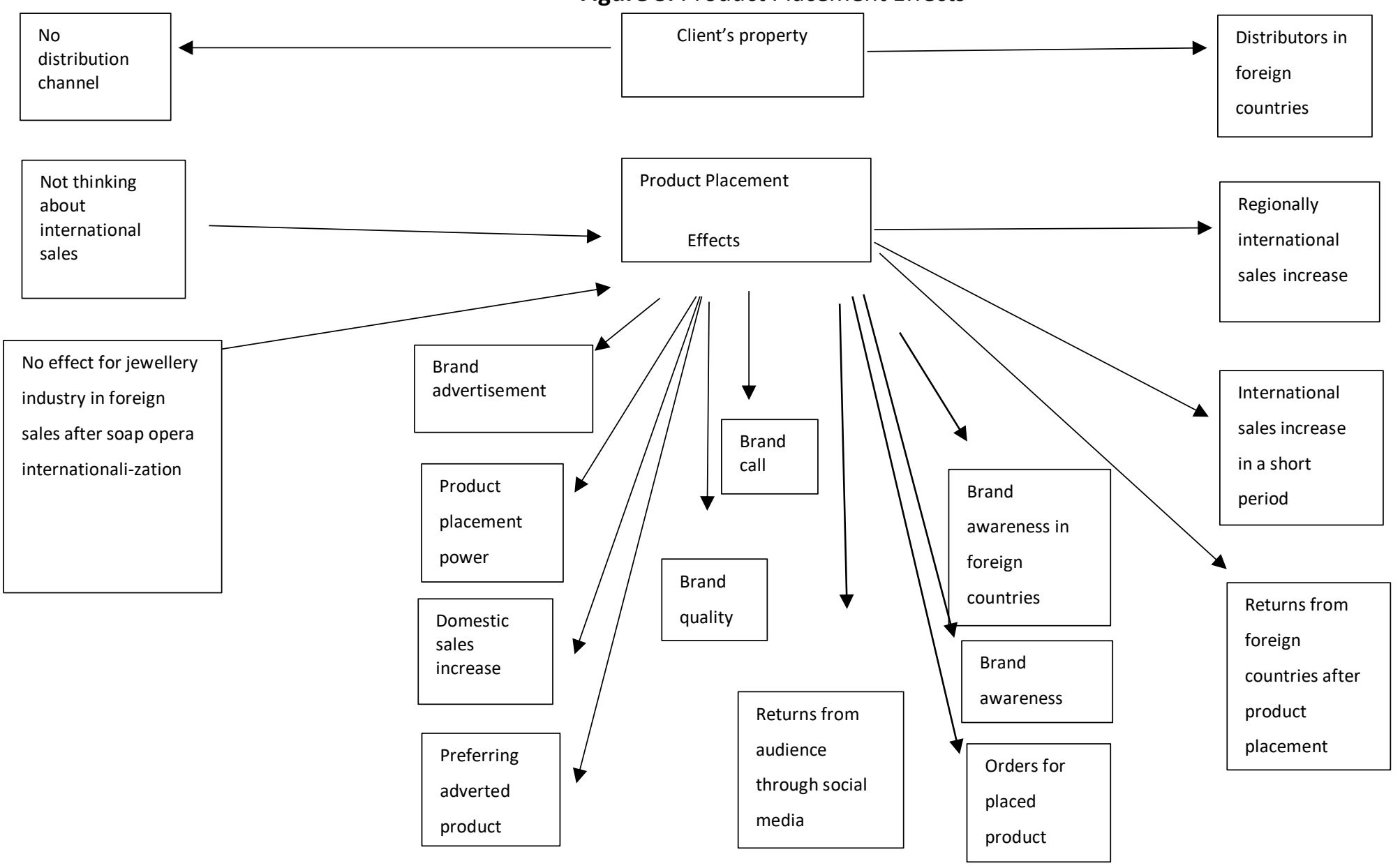


Second respondent alluded about brand advertisement, one of the effects of product placement in soap operas. This firm has chosen this promotion style till the early times of soap opera popularization, having benefits for their brands.

Aditionally according to second respondent's expresses brand awareness is reached as an effect of product placement in soap operas. This firm, reaching wide audiences from the previous product placements, believe the power of product placements. By the help of product placement they increased their brand awareness and correspondingly their sales. Thus their first aim is not increasing firm's sales. For the second respondent the first aim in product placement is increasing brand awareness. When audiences intent to enter a jewellery the firm wants to attract the customers to enter their shops.

Related with the previous effect second respondent emphasizes brand awareness in foreign countries as an another product placement effect. In countries broadcasting Turkish soap operas, through the product placement and supporting sectoral infrastructure customer demand can be seen for this firm's products. Both in Turkey and in countries broadcasting Turkish soap operas they attain brand awareness through placed product.

One of the common effects that all the respondents agree on is orders for placed product. According to second respondent, it is a provable claim, still taking domestic and international orders for the placed ring in the generics, although it is an expensive product.

Another effect of product placement in soap operas is preferring adverted product. Correspondingly the previous object, product placement has a strong effect for clients as being preferred from customers, especially the particular product that is placed in the soap opera. The first and the second respondent agree on the fact that the placed product becomes the most known product of the company. Consequently depending on respondents' examples from their product placement cases, the placed product attains the highest revenue, highest sales and becomes the most expensive product of the company. Correspondingly, customers watching these product placements are exposed the messages of the company. According these effects customers orient to these companies instead of the others. Also the placed product is preferred by customers.

Another point respondents emphasize is returns from audiences through social media after product placement. Depending on social media use, companies meet quick responses from audiences. Audiences give reaction to companies trying to reach them by tweets, messages from instagram end e-mails. They comment about the firm and the products. This proves that product placement and also the brand is noticed by audiences.

Another effect of product placement in soap operas for clients is brand call. After product placements firms expect audiences guessing their brand when audiences see a jewel in soap 
operas. This is also proved from the commentaries by audiences sending e-mails, messages from instagram, twitter. In 2005, during their first product placement, the second firm used 22 karat gold bracelett. The respondent from second firm implies that their highest sales revenue still comes from 22 karat gold bracelett. This highest sale of placed product through all the other products show the efficiency of product placement.

Product placement has another positive effect for the client, increasing brand quality. Through product placement, as number of sales point and sales increase, the customers' percieve of brand quality increase in the same time. In other words, sales point and sales increase help brand quality increase.

Another effect of product placement is coded as product placement power. All the respondents are aware of the power of product placement. Third respondent admitted that spot advertisements in soap operas are not watched by audiences. Audiences always see this time as a break of soap opera, doing different things in the past and at present. In the past clients guess audience were making tea during advertisement break. Now they are particularly sure that audiences look for social media during advertisement break. Thus, product placement being seen during watching soap opera is more effective than spot advertisement. Another positive effect of product placement is being more convincing as sometimes being integrated on the script. In this style of product placement product is used by the actors or actresses. According to the agreement between the client and the production company, actor or actresses may enter the shop of the company to show the brand. Thus, respondents imply that integrated product placement is the most effective product placement style. As an example, second firms' new collection is called Ottoman Signature Collection. Suitability of the product to the content of soap opera has more positive effects for the firm as increasing the brand call and sales of the product. During the interview, the respondent declared they will implement product placement on a soap opera about Ottoman Empirement. Consequently, all the respondents agree that product placement is preferred by clients as an element of integrated marketing communication because of increasing power.

Three of the respondents agree on an another effect of product placement for companies coded as sales increase. First respondent instanced their past campaign coming to a successful conclusion. Paying less money comparing present price, they catch on the highest sale revenue for the placed product named 'Jival star' during soap operas called The Bitter Life and Falling Leaves. Second respondent denoted about the 22 karat gold bracelett on 1001 Nights gets the highest sales revenue although 11 years has past on the soap opera.

The first and the third respondent emphasize that these sales are only in domestic form. When international sales is asked after exporting soap operas they express that product placement has no effect on international sales. From analyzing respondents' whole explanations, firms 
unknown properties that affect international sales in the research model, can be found as having a distribution channel in international area or not. This is the determining factor of evaluating international sales after product placement.

Looking from the companies having a distribution channel draws a different conclusion on international sales after product placement. On the other hand, looking from the companies not having a distribution channel draws a different conclusion on international sales after product placement. Thus, first the effects of not having a distribution channel will be explained.

Under this headline, the most important subject is that clients don't think about international sales. They focus on only domestic sales having domestic basis. The first respondent admits distribution channel as a must for sales. They have no shop in foreign countries. They have no other sales channels even corners or jewellery customers. Thus they do not target about international sales. First respondent emphasize to be reachable. He adds when audience see the product in soap operas, they have to know where they can buy that product. He also declares that if customers cannot reach the products, then product placement implementation is useless. Besides distribution channels, first respondent adds about reachability of right price and right quality.

Correspondingly, another code is attained from third respondent as product placement on exported soap operas have no effect on jewellery industry. Third respondent thinks that only one soap opera increased the diamond product sales for a short time in domestic market. Thus, he concludes no general effect for the industry is achieved after product placement on soap operas.

Different from the first and the third respondent, from the second respondent's point of view product placement increase the company's domestic and international sales. Second respondent denotes that company has 120 domestic and foreign distributors. Again having distributor and having many numbers in foreign countries composes appropriate atmosphere for consumers to reach the products.

Through the respondents' expresses two different effects, regional international sales and international sales in a short time are attained. First and third respondent, although defending that product placement had no effect on international sales, admit regional international sales in a short time. They explain this short and regional sales increase with Magnificient Century. This soap opera had a serious effect all over the World, especially on Arabic countries that the jewels used in soap opera had attracted attention by audiences. All of the respondents agree that during this soap opera both in Turkey and in broadcasted countries especially in Arabian ones, diomand products became so popular. The third respondent added that Magnificient Century had such a strong effect that the brand of the products didn't matter for the customers 
although the sponsor firm was known. In other words, customers didn't take care about the producer of diamond pruducts. Thus, all the jewellers have benefitted from the popularity of Magnificient Century and diamond products. Third respondent adds that after Magnificient Century had ended, diomand product sales come to the previous point. Thus, they emphasize international sales increase with this short time.

Also the first respondent supports this statement as seeing the popularity of Magnificient Century in Egypt, Romania, Dubai and even in Los Angeles. When they go with similar diamond product to shops, customers noticed those products as jewels in Haremin Sultan again although there is no name of the sponsor firm of Magnificient Century. Especially in Saudi Arabia, in Iran, in Dubai, in North Africa, in Morocco, in Libya, in Algeria, these products were sold seriously. Depending on the demand of customers, first respondent composed a creation and display material for these countries' traditional sales style wholesaling. During broadcasting time of Magnificient Century, these products had serious sales in a particular region in a short time for not only the sponsor firm but also the other jewellers. From this expression, regional sales increase is coded.

Another effect of product placement on exported Turkish soap operas for clients is returns after product placement in foreign countries. Having distributiors in foreign countries again the second respondent cited about returns after product placement in foreign countries. This is related with the popularity of Turkish soap operas, Turkish actors and actresses in foreign countries. Second respondent can interpret the returns after product placements as being in communication with the distributors. A distributor from Romania took several rings that were placed in the generics according to customer demand.

Related with the above factor, another effect of product placement in soap operas for clients is the returns from foreign countries after product placement. Second respondent emphasize that they had no calculation for the results of product placement. However, the commentaries from social media, purchasing behaviours and sales figures show that product placement has an effect on sales increase. The simple proof is the orders for the ring on generics. Orders also come from foreign distributors for the same ring.

\section{CONCLUSION}

Present day's competitive conditions has changed the direction of traditional marketing to the integrated marketing. This change increased the numbers of advertisement messages consumers are being exposed to. Nonetheless, the channels that advertisement messages are transmitted verified everyday. Related to other marketing communication elements, product placement is rated new. Through product placement, advertisement givers take the oppurtunity of touching consumers beside traditional methods. Advertisement givers prefer product placement by reason of decreasing the possibility of avoiding the messages in a more natural 
way than advertisements (Bas, 2013, p.1) On the other hand, in Turkish broadcast flow soap operas have very important place taking the prime time completely. Thus, advertisement givers prefer frequently soap operas for product placement. In other words, audience are exposed to so many product placement during only one episode. Being an important resource for producers, product placement support producers for high investment budgets in order to reach high quality of soap operas.

The remarkable another point on Turkish soap operas is being exported to so many countries. High quality of Turkish soap operas together with the Turkish cosmopolite culture opened a place for Turkish soap operas in the foreign countries that are poor in local products. Turkish soap operas come to a point being followed by global audiences from 100 different countries, generating more than $\mathbf{2 0 0}$ million \$ revenue. Turkey's target in media sector is stated as 1 billion \$ (http://www.ito.org.tr/wps/portal/gazetedetay?WCM GLOBAL CONTEXT=ito portal_tr/itoportal / gazete/gzt-2014gzt-2014-9/gzt-2014-9-26/a022d18045dd5 d5983e1ff174d181f0c).

Depending on this, in this research it is aimed to learn if there is increase in international sales of the clients after product placement on exported soap operas. According to the answers of respondents it is reached that there is no investigation to report the firms' international sales increase after a product placed in an exported soap opera. Thus, a tangible result cannot be pronounced about international sales position related with product placement. Consequently, this supports the results that companies focus on domestic sales and don't take into consideration about foreign sales. As a result, it is not proved that there is an increase in international sales related with product placement although respondents admit that there was regional and periodic increase in international sales. This expression is restricted with only one soap opera. In the light of foregoing, it will be better for both academicians, and the advertisement givers to learn the tangible results of international sales after product placement in the future researchs.

On the other hand, the most important contribuition of this article is listing the general product placement effects for clients looking from the window of the clients for the first time. The article firstly organizes the product placement effects and company's properties that affect product placement results in the same framework for reducing the complexity in the literature. According to respondents there are so many effects for client as brand awareness, brand call which are supported in the previous literature.

Secondly and the most important result of this article is that stating the presence of distribution channel as a parameter for evaluating the effectiveness of product placement for international sales of clients. Discourses of respondents indicate that although product placements in soap operas have great power on sales, if company has no distribution channel in countries soap operas broadcasted, companies attain no contribution from product placement. 
Thirdly, it is reached that clients focus on domestic market when placing product. Clients with no distribution channel in foreign countries don't even think about effects for international sales. Only one respondent having distribution channel in foreign countries admit paying attention for international sales of soap operas ald also their own products when deciding product placement.

Consequently, product placement ratio and soap opera export has emerged as important items for both clients and media sector. However, there is no strict information about the results of changes in both domestic and international sales after product placement in soap operas. It will be better to work on certain information for both clients and soap opera producers to be able to move on strategic plans as operating in an international market.

The results gaining from the study have a qualification for paying attention of researchers studying on product placement strategies and the managers implementing these strategies. Although this article has overviewed the basic framework of effects of product placement in Turkish soap operas for clients, there is still gaps in the literature. Even though researches on product placement frequently circle around the audiences side, the more researches on clients will express the subject better giving a deeper insight. 


\section{REFERENCES}

Argan Metin, Nurtanıs Velioglu Meltem ve Tokay Argan Mehpare (2007) "Marka yerleştirme stratejilerinin hatırlama üzerine etkisi: 'GORA' filmi üzerine arastırma”, Elektronik Sosyal Bilimler Dergisi, C.6 S.19, s. 159-178.

Aydın, Duygu ve Orta, Nermin (2005) "Sinemanın reklam aracı olarak kullanımı 'Türk filmlerinde marka yerleştirme uygulamaları"; İstanbul Üniversitesi Iletişim Fakültesi Dergisi, No:36, s. 7-23.

Babbie, Earl (2004) The practise of social research, (10 th ed.). Belmont, Wadsworth: Thomson Learning.

Babacan, Eylin, Akcalı, Selda Icin ve Baytekin, E. Pelin (2012) "Product placement as a rising marketing communication activity: an assessment on television serials"; Social and Behavioral Sciences, 62, s. $1319-1331$.

Bas, Ahmet (2013) Ürün yerleştirme ve tv dizilerinde uygulamaları üzerine bir araştırma, Unpublished Master Thesis, Istanbul: Marmara University, Social Sciences Institute.

Bas, Turker ve Akturan, Ulun (2008) Nitel arastırma yöntemleri- NVivo 7.0 ile nitel veri analizi. (Birinci Baskı), Ankara: Seçkin.

Bernard, H. Russell ve Ryan, Gery (2010) Analyzing qualitative data systematic approaches. California: Sage.

Corbin, Juliet ve Strauss, Anselm (1998) Basics of qualitative research- techniques and procedures for developing grounded theory, (2nd ed.). London: Sage.

D’astous, Alain ve Séguin, Nathalie (1999) Consumer reactions to product placement strategies in television sponsorship. European Journal of Marketing, Vol. 33 Issue: 9/10, p. 896-910.

Denzin, Norman K. ve Lincoln, Yvonna S. (2000) Handbook of qualitative research, (2nd ed.). California: Sage.

Gould, Stephen. J., Gupta, Pola B. ve Grabner-Krauter, Sonja (2000) "Product placements in movies: A cross-cultural analysis of Austrian, French and American consumers' attitudes toward this emerging, international promotional medium"; Journal of Advertising, 29:4, p. 41-58. 
Gregorio, Federico ve Sung, Yongjun (2010) “Understanding attitudes toward and behaviors in response to product placement"; Journal of Advertising, 39:1, p. 83-96.

Gupta, Pola B. ve Lord, Kenneth R. I. (1998) "Product placement in movies: The effect of prominence and mode on audience recall" Journal of Current Issues \& Research in Advertising, 20:1, p. 47-59.

(http://www.hurriyet.com.tr/turk-dizileri-2-numara-40417302, 4 April 2017)

(http://www.ito.org.tr/wps/portal/gazetedetay?WCM GLOBAL CONTEXT=ito portal_tr/ito-portal / gazete/gzt-2014gzt -2014-9/gzt-2014-9-26/a022d18045dd5 d5983e1ff174d181f0c) (4 April 2017)

Jin, Chang Hyun ve Villegas, Jorge (2007) "The effect of the placement of the product in film: Consumers' emotional responses to humorous stimuli and prior brand evaluation"; Journal of Targeting, Measurement and Analysis for Marketing, Vol. 15, 4, p. 244-255.

Kale, G. B. (2014) Türkiye'de Ulusal Kanallarda Yayınlanan Durum Komedisi Dizilerindeki Ürün Yerleştirmenin Pazarlama iletişimine Etkisi, Unpublished Master Theses, Istanbul: T.C. Okan University.

Karrh, James, McKee, Kathy Brittain ve Pardun, Carol J. (2003) “Practitioners' evolving views on product placement effectiveness"; Journal of Advertising Research, June.

Lehu, Jean Marc ve Bressoud, Etienne (1990) "Effectiveness of brand placement: New insights about viewers"; Journal of Business Research, 61, p. 1083-1090.

Mayring, Philipp (2000) Nitel sosyal arastırmaya giriş. çev: Adnan Gümüs, M. Sezai Durgun, Adana: Baki.

Newell Jay, Salmon Charles T., ve Changs Susan (2006) "The hidden history of product placement", Journal of Broadcasting \& Electronic Media, 50:4, p. 575-594.

Pastina, Antonio C. La (2001) "Product placement in Brazilian prime time television: The case of the reception of a telenovela"; Journal of Broadcasting \& Electronic Media, 45(4), p. 547557.

Pervan, Simon J. ve Martin, Brett A. S. (2002). "Product placement in US and New Zealand television soap operas: An exploratory study"; Journal of Marketing Communications, 8:2, p. 101-113. 
Reijmersdal Eva van, Smit Edith G. ve Neijens Peter (2010) "How media factors affect audience responses to brand placement"; International Journal of Advertising, 29:2, p. 279301.

Russell, Cristel Antonia ve Belch, Micheal (2005) "A managerial investigation into the product placement industry"; Journal of Advertising Research, February.

Russell, Cristel Antonia ve Stern, Belch (2006a) "Consumers, characters, and products: A balance model of sitcom product placement effects"; Journal of Advertising, 35:1, p. 7-21.

Russell, Cristel Antonia ve Stern, Belch (2006b) "Consumption in soap operas from Brazil, New Zealand, and the U.S."; Production, products, and process, advances in consumer research, Volume 33.

Sapmaz, Emel ve Tolon, Metehan (2014) "Bütünleşik pazarlama iletişiminde ürün yerleştirme ve üniversite öğrencilerinin televizyon programlarındaki ürün yerleştirmelere ilişkin tutumlarına yönelik bir araştırma"; Gazi Üniversitesi iktisadi ve Idari Bilimler Fakültesi Dergisi, 16/2, s. 15-44.

Snyder, Steven L. (1992) "Movies and product placement: Is Hollywood turning films into commercial speech?"; University of Illınois Law Review, p. 301-337.

Van Der Waldt, Dlr., Toit, Ls. Du. and Redelinghuys R. (2007) "Does branded product placement in film enhancerealism and product recognition by consumers?"; African Journal of Business Management, p. 019-025.

Yıldırım, Ali ve Simsek, Hasan (1999) Sosyal bilimlerde nitel arastırma yöntemleri, (1. Baskı). Ankara: Seckin.

Yıldırım, Ali ve Simsek, Hasan (2008) Sosyal bilimlerde nitel arastırma yöntemleri, (7. Baskı). Ankara: Seckin. 